\title{
Variability of early diagenesis in lake sediments: Evidence from the sedimentary geolipid record in an isolated tarn
}

\author{
Eileen S. Ho and Philip A. Meyers \\ Department of Geological Sciences, The University of Michigan, Ann Arbor, MI 48109-1063, USA
}

(Received November 10, 1992; revised and accepted July 14, 1993)

\begin{abstract}
A 0.5-m-long core of sediment from Coburn Mountain Pond, Maine, U.S.A., has provided a virtually undisturbed and continuous record of sediment deposition for the last $200 \mathrm{yr}$ in this small, essentially pristine tarn. Organic carbon concentrations, $\mathrm{C} / \mathrm{N}$ ratios, carbon isotopic compositions and extractable hydrocarbon molecular compositions indicate subtle differences in the sources of organic matter between sediments deposited before and after ca. 1950 but are otherwise constant. In contrast, total concentrations and molecular distributions of $n$-fatty acids and $n$-alkanols vary considerably. The fatty acid and alkanol geolipid fractions are both sensitive to early diagenetic alteration, yet the two fractions react differently. Concentrations and compositional parameters such as long/short, even/odd and branched/unbranched ratios fluctuate with sediment depth, and reflect amounts of microbial reworking which have varied repeatedly over the depositional history. $n$-Alkane distributions are relatively unaffected by the short-term changes and therefore better preserve the history of biolipid sources to the sediments.
\end{abstract}

\section{Introduction}

The geolipid fraction of organic matter constitutes a minor but important portion of lake sediments. This fraction contains many of the biomarkers derived from the multitude of aquatic and watershed organisms that are the primary sources of sedimentary organic matter. It also contains the secondary biomarkers which are created by microbes during the early diagenetic reworking of the primary forms of organic matter.

A number of workers have employed geolipid biomarkers and their distributions to infer histories of organic matter accumulations in freshwater lake sediments. Organic matter inputs over postglacial and longer periods of depositional history have been characterized using the combined distributions of alkanes, fatty acids, alcohols and sterols in sediments from Mono Lake, California, U.S.A. (Reed,
1977), Cam Loch, Sutherland, U.K. (Cranwell, 1977), Heart Lake, New York, U.S.A. (Meyers et al., 1984a) and Voua de la Motte, France (Wünsche et al., 1988). Studies of geolipid compositions of sediments from oligotrophic and eutrophic lakes have indicated that the rate of aquatic primary production is important both to the types of organic material incorporated into lake sediments and to its degree of diagenetic reworking (Cranwell, 1978, 1981; Cranwell and Volkman, 1981; Kawamura and Ishiwatari, 1985; Cranwell et al., 1987). Straight-chain acids and alcohols, in particular, appear to be especially sensitive to early diagenetic alteration (Meyers et al., 1980a, b; Kawamura and Ishiwatari, 1984), whereas hydrocarbon molecules are more resistant to such changes and thereby provide better indications of their origins (e.g., Giger et al., 1980; Prahl and Carpenter, 1984; Cranwell et al., 1987). Most of these studies have presumed that geolipid components generally 
undergo steady, progressive diagenetic alteration.

Some early diagenetic alterations of the geolipid contents of lacustrine sediments appear to follow first-order kinetics. The contributions of $\mathrm{C}_{14}, \mathrm{C}_{16}$ and $\mathrm{C}_{18}$-alkanoic acids to total organic matter decrease exponentially with depth in the sediments of Lake Suwa, Japan (Matsuda and Koyama, 1977a) and Lake Huron, North America (Meyers et al., 1980a). The proportions of unsaturated acids decrease similarly with sediment depth in these two lakes and also in Lake Haruna, Japan (Kawamura et al., 1980). These depth-related alterations in geolipid contents are typically accompanied by increases in the relative abundance of branched-chain alkanoic acids, suggesting that microbial activity has participated in the changes (cf. Matsuda and Koyama, 1977b; Meyers et al., 1980a).

Consistent depth-related diagenetic trends in geolipid compositions are not found in all lake sediments, however. Variations in depositional or lacustrine conditions evidently provoke perturbations in rates of early diagenesis. Mendoza et al. (1987), for example, showed that an interlude of postulated higher rate of sedimentation and consequent diminished diagenesis created sub-bottom maxima in the concentrations of $n$-alkanoic acids and in the contributions of unsaturated acids in the sediments of Lac Léman, Switzerland. Similarly, Meyers et al. (1980c) concluded that a pulse of rapid sediment accumulation temporarily enhanced fatty acid preservation in Pyramid Lake, Nevada, U.S.A., and produced an accompanying increase in the proportions of unsaturated acids. Furthermore, Meyers (1990) showed that fluctuations in the water level of Walker Lake, Nevada, U.S.A., led to alternations of enhanced and diminished diagenesis of sediment organic matter. Changes in the type of primary organic matter, moreover, can accompany the changes in depositional conditions which are postulated to impact the extent of diagenesis. The consequences of possible source changes must be considered along with those of diagenesis.

As part of our continuing comparisons of organic matter sources and diagenesis in different lacustrine systems, we report here the results of our analyses of geolipids in the sediments of Coburn Mountain Pond, an isolated and essentially pristine tarn situated in the northeastern U.S.A.

\section{Materials and methods}

\subsection{Coburn Pond sediments}

Coburn Mountain Pond is a small (2.6 ha), shallow (3.5 m maximum), oligotrophic lake located $837 \mathrm{~m}$ above sea level (a.s.l.) in northwestern Maine, U.S.A. $\left(45^{\circ} 28^{\prime} \mathrm{N}, 70^{\circ} 08^{\prime} \mathrm{W}\right)$. The top of Coburn Mountain is at $1140 \mathrm{~m}$ a.s.l., so the position of the tarn high on the mountain makes it relatively isolated from environmental changes. The watershed is forested predominantly with fir and spruce, and it is largely undisturbed. Some logging may have occurred the 1930's, but none has been done since then (Norton et al., 1981). No roads or settlements now exist in the catchment area.

The sediment of Coburn Mountain Pond is a dark-gray gyttja. Its water content averaged $95 \%$ in the $0.5-\mathrm{m}$ core that was obtained in July 1978 from the deepest part of the lake by S.A. Norton and R.B. Davis from the University of Maine. The 10-cm-diameter core was sectioned into 1- and 2-cm intervals which were refrigerated prior to geolipid extraction in early 1980. We selected seventeen core samples for our study of geolipid sources and diagenesis (Table 1).

Atmospheric delivery of anthropogenic pollutants to Coburn Mountain Pond has been investigated using the core from which we obtained samples. Norton et al. (1981) reported major-element and total organic matter contents of the core sections, and Gschwend and Hites (1981) determined the fluxes of pyrogenic polycyclic aromatic hydrocarbons 
TABLE 1

Sedimentation data for the core sections sampled from Coburn Mountain Pond, Maine

\begin{tabular}{ccll}
\hline $\begin{array}{l}\text { Core } \\
\text { interval } \\
(\mathrm{cm})\end{array}$ & $\begin{array}{l}\text { Average } \\
\text { age } \\
(\mathrm{yr})\end{array}$ & $\begin{array}{l}\text { Sedimentation } \\
\text { rate }^{\mathrm{b}} \\
\left(\mathrm{cm} \mathrm{yr}^{-1}\right)\end{array}$ & $\begin{array}{l}\text { Water } \\
\text { content }^{\mathrm{c}} \\
\left(\mathrm{wt}^{\mathrm{a}}\right)\end{array}$ \\
\hline $0-2$ & 2.5 & 0.40 & 96.5 \\
$3-4$ & 8.75 & 0.40 & 94.8 \\
$5-6$ & 13.75 & 0.40 & 94.6 \\
$7-8$ & 18.75 & 0.40 & 94.6 \\
$9-10$ & 25.0 & 0.38 & 94.5 \\
$10-12$ & 32.5 & 0.20 & 94.9 \\
$14-16$ & 52.5 & 0.20 & 95.9 \\
$17-18$ & 65.0 & 0.20 & 95.7 \\
$20-21$ & 80.0 & 0.20 & 95.3 \\
$23-24$ & 95.0 & 0.20 & 94.7 \\
$26-27$ & 110.0 & 0.20 & 94.4 \\
$29-30$ & 125.0 & 0.20 & 94.5 \\
$32-33$ & 140.0 & 0.20 & 95.0 \\
$35-36$ & 155.0 & 0.20 & 94.7 \\
$37-39$ & 167.5 & 0.20 & 94.4 \\
$40-42$ & 182.5 & 0.20 & 94.3 \\
$43-45$ & 197.5 & 0.20 & 94.3 \\
\hline
\end{tabular}

age is number of years from 1978, which is at top of core.

bCalculated by Gschwend et al. (1983).

'Determined by Norton et al. (1981).

(PAH) to these sediments. In addition, Gschwend et al. (1983) calculated the apparent first-order diagenetic formation of perylene in subsamples of the geolipid extracts we have subsequently examined. The heavy-metal (e.g., $\mathrm{Pb}$ ) and pyrogenic PAH loadings to the sediments preserve the histories of atmospheric contributions of these contaminants, and indicate that the sediments have not experienced any major redistribution disturbances. Bioturbation appears to be limited to the upper $2 \mathrm{~cm}$, and sediment pore waters are anoxic beneath this mixed zone. The approximate years of deposition of selected core depths we provide herein (Table 1) are based on the ${ }^{210} \mathrm{~Pb}$ and ${ }^{137} \mathrm{Cs}$ data of Norton et al. (1981).

\subsection{Carbon concentrations, $C / N$ ratios and stable isotope ratios}

Concentrations of total and inorganic carbon were determined on extracted sediment samples using a Coulometrics ${ }^{\circledR} 5010$ coulometer (cf. Engleman et al., 1985). In the procedure using this instrument, total carbon is combusted at $950^{\circ} \mathrm{C}$ to $\mathrm{CO}_{2}$ and carbonate carbon is converted to $\mathrm{CO}_{2}$ by treatment with $\mathrm{HCl}$. The amounts of $\mathrm{CO}_{2}$ liberated by each treatment are measured by titration in a monoethanolamine solution with a colorimetric indicator. The difference in concentrations of total carbon and carbonate carbon is taken to be the organic carbon concentration.

Organic carbon concentrations were also measured directly with a Carlo Erba ${ }^{\star} 1108$ CHNS analyzer, which also provided organic matter $\mathrm{C} / \mathrm{N}$ ratios. This instrument combusts the sediment samples at $1020^{\circ} \mathrm{C}$ and chromatographically separates and quantifies the combustion gases (cf. Verardo et al., 1990). No sediment pretreatment to remove carbonate carbon was done, inasmuch as the coulometric analyses revealed essentially no inorganic carbon $(<0.01 \%)$ in these samples.

Carbon isotope measurements were done on the extracted core sections in the Stable Isotope Laboratory at The University of Michigan. The ${ }^{13} \mathrm{C} /{ }^{12} \mathrm{C}$ ratios of organic carbon were measured with a Finnigan ${ }^{\otimes}$ Delta $S$ mass spectrometer after oxidation of the sediment organic matter to $\mathrm{CO}_{2}$ by heating with $\mathrm{CuO}_{2}$ at $800^{\circ} \mathrm{C}$ in a sealed and evacuated quartz tube. Results are corrected for ${ }^{17} \mathrm{O}$ and are reported in per mil relative to the PDB standard.

\subsection{Geolipid extractions and fractionation}

Solvent-extractable geolipids were obtained by Soxhlet extraction of wet sediment samples with a $1: 1$ toluene-methanol mixture for $48 \mathrm{hr}$. The extraction solvent was replaced twice during the extraction to accommodate the water that was removed from the sediments. The extraction mixture was then back-extracted with dichloromethane, which was evaporated to yield the solvent-extractable material.

The geolipid extracts were transferred to reaction vessels with benzene, heated with a sa- 
ponification mixture $(0.5 \mathrm{~N} \mathrm{KOH}$ in $95 \%$ methanol), and subsequently treated with methanolic boron trifluoride. This procedure converts free and formerly esterified fatty acids to their methyl esters in preparation for gas chromatographic analysis (Murphy, 1969; Meyers and Takeuchi, 1979).

The total geolipid extracts were separated into lipid fractions by silica gel-alumina column chromatography (Leenheer et al., 1984). Each sample extract was concentrated in petroleum ether, adsorbed onto aluminum oxide, and added to a column consisting of $5 \%$ deactivated silica gel, $5 \%$ deactivated aluminum oxide and a thin top layer of elemental copper (for removal of elemental sulfur). Geolipid fractions were successively eluted with a series of solvents: aliphatic hydrocarbons (petroleum ether), aromatic hydrocarbons ( $85: 15$ petroleum ether-benzene), fatty acid methyl esters (benzene), alcohols ( $1: 1$ ethyl acetate-benzene) and a column wash (dichloromethane). The alcohol fractions were treated with bis-(trimethylsilyl)-trifluoroacetamide to form trimethylsilyl ether derivatives. Prior to gas chromatography, an internal standard of $5 \alpha(\mathrm{H})$-cholestane was added to each fraction.

\subsection{Geolipid analysis}

Hydrocarbon, fatty acid methyl ester and fatty alcohol silyl ether fractions of solvent-extractable sediment geolipids were analyzed using a Hewlett-Packard ${ }^{\star}$ 5830A FID gas chromatograph equipped with a $20 \mathrm{~m} \mathrm{SE}-54^{\circledR}$ fused silica capillary column and a split/splitless capillary inlet system. Hydrogen was the carrier gas, and nitrogen was the make-up gas. Oven temperature was programmed from $120^{\circ}$ to $270^{\circ} \mathrm{C}$ at $6^{\circ} \mathrm{C} \mathrm{min}^{-1}$, with a 20 -min hold at maximum temperature. Mixtures of authentic standards were regularly injected to provide retention time indices and mass discrimination response correction factors. Identifications and quantifications of specific alkanes, alkanoic acids and alkanols were based on retention times of the authentic standards, the internal standard amounts and detector response factors.

\section{Results and discussion}

Extrapolation of the radiometric data indicates that this $0.5-\mathrm{m}$ core records approximately the last 200 years of sediment accumulation in Coburn Mountain Pond. Gschwend et al. (1983) conclude from the radiometric data and from dilution of anticipated perylene concentrations that sediments above the $9-\mathrm{cm}$ horizon were deposited about twice as fast as those deeper in the core (Table 1).

A color change occurs over the $7-12-\mathrm{cm}$ depth range in the sediments and coincides with the change in sedimentation rate. The dry, extracted samples in this interval were perceptively darker than those both shallower and deeper. This depth range corresponds to the period 1960-1948 (Gschwend et al., 1983). Nothing is indicated in available historical records that would identify a specific change in the lake-watershed system over this period. It remains noteworthy that the heavy metal and pyrogenic PAH data record no postdepositional sediment disturbance despite the changes in color and sedimentation rate.

\subsection{Carbon concentrations, $C / N$ ratios and stable isotope ratios}

Nearly all of the carbon in the sediments of this acid tarn is contained in organic matter; $<0.1 \%$ is present as $\mathrm{CaCO}_{3}$. Organic carbon concentrations vary between 21 and $25 \%$ (Fig. 1). Sediments in the upper $10 \mathrm{~cm}$ of the core have somewhat lower concentrations than deeper sediments, and the concentration maximum occurs in the 10-12- and 14-16-cm intervals, corresponding to $1950-1930$. The decrease in organic carbon contents of the upper sediments coincides with the doubling of sedimentation rate (Gschwend et al., 1983). This 


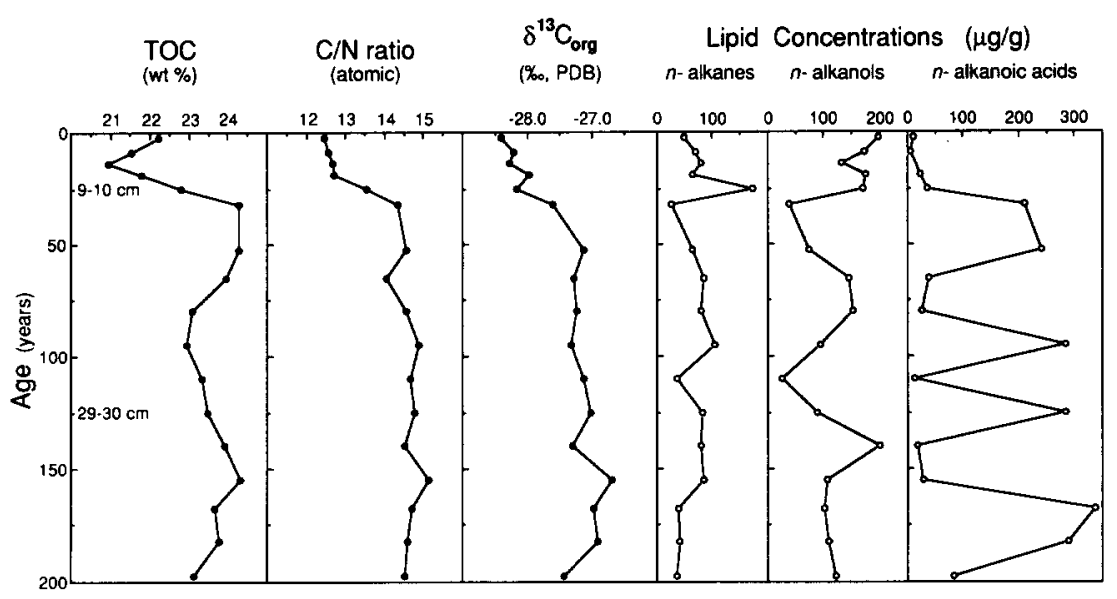

Fig. 1. Total organic carbon (TOC) percentages, organic matter atomic $\mathrm{C} / \mathrm{N}$ ratios, organic carbon $\delta^{13} \mathrm{C}$-values and concentrations of total extractable hydrocarbons, alkanols and fatty acids ( $\mathrm{mg} / \mathrm{g}$ sediment) of samples from Coburn Pond sediment core. Approximate ages of sediment as determined by ${ }^{210} \mathrm{~Pb}$ and ${ }^{137} \mathrm{Cs}$ radiodating by Norton et al. (1981) are indicated.

change may therefore simply reflect dilution of organic matter by mineral sediment components. The decrease in organic carbon percentage, however, is only $5 \%$ relative to deeper sediments. If mineral dilution alone were responsible, the expected decrease would be $50 \%$, inasmuch as the sedimentation rate doubles. The rate of burial of organic matter has evidently increased in the upper $10 \mathrm{~cm}$ of these sediments, indicating probable changes in both delivery and preservation of organic matter.

Organic matter $\mathrm{C} / \mathrm{N}$ atomic ratios are between 12.5 and 15.2 throughout the core (Fig. 1). Organic matter produced by algae and microbes has $\mathrm{C} / \mathrm{N}$ values which average between 5 and 8, whereas land-plant organic matter has ratios averaging between 20 and 100 (cf. Jasper and Gagosian, 1989). The values in Coburn Pond evidently indicate a mixture of contributions of organic matter from algal, microbial and higher-plant sources.

A small but consistent shift to lower $\mathrm{C} / \mathrm{N}$ values appears in sediments deposited since 1950 (Fig. 1). This pattern is opposite to the diagenetic decrease in $\mathrm{C} / \mathrm{N}$ values with time which has been documented in soils (Sollins et al., 1984) and reported for lake sediments (Hatcher et al., 1982). The observed change in $\mathrm{C} / \mathrm{N}$ ratios must instead signal some change in the types of organic matter delivered to and buried in the sediments of this tarn before and after 1950.

Organic carbon stable isotopic ratios range between -28.5 and $-26.5 \%$ and, like the $\mathrm{C} /$ $\mathrm{N}$ ratios, change at the 1950 depositional horizon (Fig. 1). The isotopic values are typical of organic matter synthesized by $\mathrm{C}_{3}$ plants from $\mathrm{CO}_{2}$ dissolved in fresh water or present in the atmosphere (cf. Jasper and Gagosian, 1989). The shift to lighter $\delta^{13} \mathrm{C}$-values in the top 10 $\mathrm{cm}$ suggests that a change occurred either in the type of organic matter which accumulated in the tarn sediments after ca. 1950 or in the amount of diagenetic alteration of the sedimented organic matter.

Changes in both watershed plant types or in aquatic productivity would impact the sedimentary isotopic record. Sackett et al. (1986) interpreted a shift in $\delta^{13} \mathrm{C}$-values from $-27 \%$ in Lake Ontario, North America, sediments deposited prior to 1860 to $-24.7 \%$ in recent sediments to record a transition in watershed plants from native $\mathrm{C}_{3}$ types to introduced agricultural $\mathrm{C}_{4}$ grasses. The isotopic values in Coburn Pond might possibly record an opposite change in watershed plant types, that is, to 
increasing dominance of shrubs and trees in recent times, but no evidence supports this type of change. Enhanced lacustrine productivity would diminish availability of dissolved $\mathrm{CO}_{2}$ and yield heavier organic carbon isotope values (e.g., Hollander and McKenzie, 1991), rather than the lighter values found in Coburn Pond. The shift in organic carbon $\delta^{13} \mathrm{C}$ in Lake Ontario sediments has been subsequently reinterpreted as being a byproduct of cultural eutrophication of this lake (Schelske and Hodell, 1991 ). A common consequence of enhanced aquatic productivity is a change in the dominant biotic assemblage, and this change can impact the carbon isotope composition of algal organic matter. For example, blue-green algae typically have heavier $\delta^{13} \mathrm{C}$-values than those of diatoms (e.g., Meyers, 1990; Hollander and McKenzie, 1991). The shift in the more recent Coburn Pond isotope record is not obviously consistent with an algal productivity increase.

Laboratory diagenesis simulation studies have demonstrated that isotopic shifts occur in fresh plant debris (Benner et al., 1987). Studies of lake sediments have similarly revealed isotopic shifts during early diagenesis of sedimentary organic matter (Hatcher et al., 1983). The reported shifts occur in material rich in organic carbon, like the sediments of Coburn Pond, and they typically lead to isotope values $\sim 4 \%$ lighter than surface values. This change is opposite to the pattern found in the sediments of Coburn Pond (Fig. 1). The isotope shift from an average of $-28.2 \%$ in the upper sediments to an average of $-27.2 \%$ in sediments deposited prior to 1950 therefore cannot easily be ascribed to early diagenesis in this tarn.

Although the observed organic carbon isotopic shift appears to be inconsistent with either enhanced aquatic productivity or early diagenesis, there remain several possible explanations which might result from lake-water acidification. The measured lake water $\mathrm{pH}$ is 4.7 (Norton et al., 1981), which is quite low, even for lakes with granitic watersheds like Coburn Pond. Norton et al. (1981) postulate from sediment trace-metal profiles that the waters of this tarn experienced acidification from acid rain starting ca. 1950. It is possible that the algal assemblage underwent change at this time, thereby modifying the organic carbon isotopic composition. Moreover, acidified lake waters would accommodate higher $p_{\mathrm{CO} 2}$, which would also lead to more negative $\delta^{13} \mathrm{C}$ values in aquatic organic matter (e.g., Hollander and McKenzie, 1991). Carbon concentrations indicate that the organic matter accumulation rate has actually increased since 1950 (Fig. 1), possibly because of enhanced algal productivity. We do not have the microfossil information that would readily resolve these questions about the history of algal populations, but our geolipid data can address the possibility of productivity change.

\subsection{Concentrations of total geolipid fractions}

Against the background of consistent patterns in total organic carbon concentrations, elemental ratios and isotopic compositions, considerable variability appears in the concentrations of total hydrocarbons, total alkanoic acids and total alkanols present at different sediment depths (Fig. 1). The alkanoic acids and alkanols, in particular, vary substantially. For example, the acids range between 6 and 338 $\mathrm{mg} / \mathrm{g}$ dry sediment, and the alkanols range between 25 and $202 \mathrm{mg} \mathrm{g}^{-1}$. The enhanced variation in these two classes of geolipids reflects their higher abundance in biota, their greater susceptibility to alteration, and therefore their higher sensitivity to early diagenesis. These fluctuations show no relationship to the total organic carbon concentrations, $\mathrm{C} / \mathrm{N}$ ratios, or the $\delta^{13} \mathrm{C}$ depth profiles (Fig. 1 ).

The maximum concentration of total hydrocarbons $\left(173 \mathrm{mg} \mathrm{g}^{-1}\right.$ ) occurs at the $9-10-\mathrm{cm}$ sediment depth, corresponding to ca. 1950. This concentration is over twice the average ( $69 \mathrm{mg} \mathrm{g}^{-1}$ ) for the core. Gschwend and Hites 
(1981) found the maximum occurrence of eolian pyrogenic $\mathrm{PAH}$ in these sediments at the 9-10-cm horizon, and Ho et al. (1991) reported that the $n$-alkane distribution of this section resembled a fossil fuel distribution. The hydrocarbon concentration maximum therefore appears to represent a short period of airborne contamination of Coburn Mountain Pond around 1950. Its concentrated expression is further evidence of little postdepositional sediment disturbance. Other than the enhanced value at $9-10 \mathrm{~cm}$, concentrations of total $n$-alkanes change little with sediment depth, suggesting that no major change occurred in the deposition of lipid material over the history of this core.

The geolipid fraction having the highest concentrations and the greatest downcore variability is the $n$-alkanoic acids, and its variation is markedly greater than that of total organic carbon (Fig. 1). The absence of major changes in the concentrations of total organic carbon and of total $n$-alkanes implies that the principal sources and contributions of organic matter to the sediments of this tarn did not undergo significant variation over the past 200 years. The fluctuations evident in $n$-alkanoic acid and $n$-alkanol concentrations may therefore reflect variations in the amount of diagenetic alteration of sediment organic matter. The almost inverse relationship between concentrations of $n$-alkanoic acids and $n$-alkanols (Fig. 1) suggests that these two geolipid classes are affected oppositely, yet in some related fashion, by early diagenesis. The important diagenetic factors are likely to include differences in susceptibility to degradation and in the amount of microbial substitution of secondary components for the original geolipid components.

\subsection{Aliphatic hydrocarbon compositions}

Molecular distributions of the seventeen core sections were analyzed to assess the sources of this geolipid fraction and to identify indicators of hydrocarbon diagenesis. Distributions of the extractable $n$-alkanes show a bimodal distribution with concentration maxima centered at $\mathrm{C}_{17}$ and $\mathrm{C}_{27}$, or $\mathrm{C}_{29}$ (Fig. 2). A strong odd/even chain-length carbon number predominance exists in nearly all the $n$-alkane distributions; the ratio is between 3.7 and 5.5 for all except the 9-10-cm section (see Fig. 4), where it drops to 1.2 due to postulated combustion hydrocarbon input (Ho et al., 1991). Maintenance of these relatively high odd/even values indicates good preservation of the original biological character of the hydrocarbon contents in these organic-carbon-rich sediments.

Scalan and Smith (1970) devised a numerical assessment of the extent of deviation of straight-chain lipid distributions from their initial biological compositions. The odd/even predominance (OEP) essentially consists of a moving calculation of odd/even carbon-chainlength preferences over a range of five consecutive $n$-alkanes; highly altered parts of chainlength distributions approach unity at specific $n$-alkanes. OEP values of the three distributions displayed in Fig. 2 are above unity throughout the range of $n-\mathrm{C}_{17}$ to $n-\mathrm{C}_{31}$, and are highest at the algal biomarker $\left(n-\mathrm{C}_{17}\right)$ and land-plant biomarker $\left(n-\mathrm{C}_{29}\right.$ and $\left.n-\mathrm{C}_{31}\right)$ parts of the distributions (Fig. 3).

The presence of a large proportion of $n-\mathrm{C}_{17}$ in the hydrocarbon distributions in the upper sediments is indicated by short/long $n$-alkane ratios above 0.4 (Fig. 4), recording important contributions of lipid matter from algal productivity (e.g., Blumer et al., 1971; Giger et al., 1980; Cranwell, 1982). The proportion of $n$ $\mathrm{C}_{17}$ diminishes progressively with sediment depth (Figs. 3 and 4), possibly indicating gradual preferential microbial degradation of shorter-chain-length $n$-alkanes with time (e.g., Giger et al., 1980; Cranwell, 1984). Alternatively, aquatic productivity may have become elevated since ca. 1950 . Although organic carbon concentrations are somewhat lower in more recent sediments (Fig. 1), the doubled sedimentation rate (Gschwend et al., 1983) 

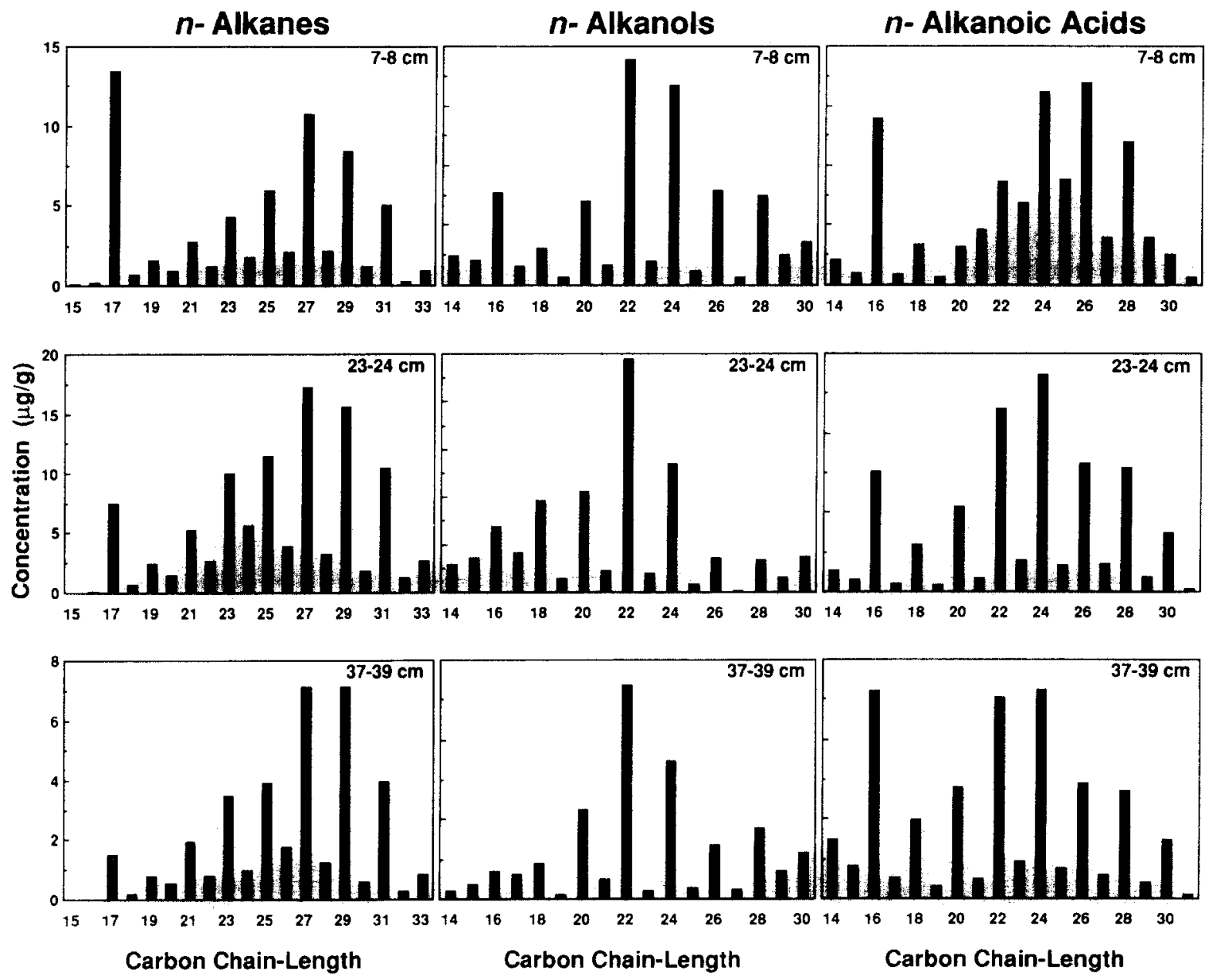

Fig. 2. Chain-length distributions of $n$-alkanes, $n$-alkanols and $n$-alkanoic acids from three representative core sections from Coburn Mountain Pond, Maine. Contribution of each component is relative to major component (100\%). Note dominance of odd-carbon-numbered $n$-alkanes and even-carbon-numbered $n$-alkanols and $n$-alkanoic acids.

has produced a greater organic carbon accumulation rate since that time. The combination of lowered $\mathrm{C} / \mathrm{N}$ ratios (Fig. 1), a greater proportion of algal $n-\mathrm{C}_{17}$, and of elevated accumulation of sediment organic matter is strong evidence of an increase in lake productivity in conjunction with lake acidification starting around 1950.

Short/long $n$-alkane ratios less than one record that land-plant epicuticular waxes have been important sources of lipids to the sediments of this tarn for several centuries (cf. Eglinton and Hamilton, 1963, 1967; Cranwell, 1973a; Rieley et al., 1991). The long carbon- chain-length hydrocarbons are less susceptible to diagenesis than are the shorter-chain algal hydrocarbons (Giger et al., 1980; Cranwell, 1984), and their absolute concentrations change little with sediment depth (Ho et al., 1991). These hydrocarbon components appear to retain a record of the original source of sediment lipids which is only slightly affected by early diagenesis. In support of this concept, an abrupt shift to higher values occurs in the ratios of $\mathrm{C}_{31} / \mathrm{C}_{27}$ and of $\mathrm{C}_{29} / \mathrm{C}_{27} n$-alkanes at the 1950 sedimentary horizon; further gradual increases are present near the bottom of this sediment core (Fig. 4). Cranwell (1973a) and 


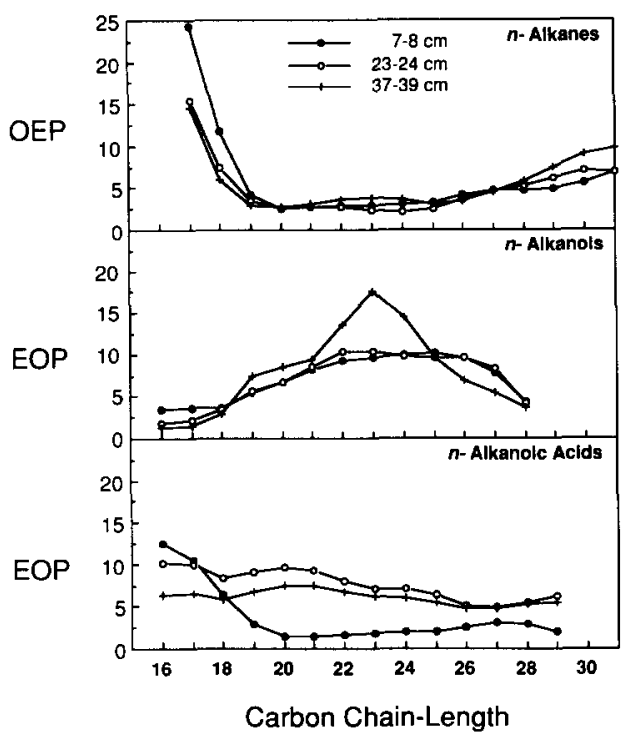

Fig. 3. Odd/even (OEP) and even/odd (EOP) predominances of $n$-alkanes, $n$-alkanoic acids and $n$-alkanols from three representative core sections of Coburn Pond sediments. OEP patterns are calculated by the formula developed by Scalan and Smith (1970), and EOP patterns are calculated by a formula adapted from the OEP formula.

Cranwell et al. (1987) have shown that $n$-alkane distributions in sediments of oligotrophic lakes provide an approximate record of plant types in the watershed. In lakes where grasses dominate the drainage area, $n-C_{31}$ is often the major sediment $n$-alkane whereas $n$ $\mathrm{C}_{27}$ and $n-\mathrm{C}_{29}$ are typically the major $n$-alkanes where deciduous trees dominate. The gradual changes in the $C_{31} / C_{27}$ and the $C_{29} / C_{27}$ ratios deeper in the core might be due to diagenesis, although it is unlikely that $n-\mathrm{C}_{27}$ would be significantly more subject to diagenetic degradation than is $n-C_{29}$. The abruptness of the shallower change suggests a modification in watershed biota to proportionally more tree and shrub coverage since ca. 1950. The isotopic shift to more recent lighter $\delta^{13} \mathrm{C}$-values (Fig. 1) is consistent with the postulated change in watershed plant types. A source modification of this type might also involve a decrease in the amount of emergent water plants in Coburn Pond, but the historical record provides no evidence that such a change in biota has occurred; the necessary pollen data are not available. The actual cause of this shift in long-chain $n$-alkane composition remains problematic in the sedimentary record of Coburn Mountain Pond, yet it seems that some sort of source change is the best explanation for the differences in organic contents above and below $10 \mathrm{~cm}$ in the core.

The isoprenoid hydrocarbon phytane is present in all core sections and is equal or more abundant than the closely eluting $\mathrm{C}_{18} n$-alkane, which is typical for young sediments (ten Haven et al., 1987). An important source of phytane is from methanogenic bacteria (Risatti et al., 1984), which exist in the anoxic conditions commonly found beneath the zone of bioturbation in all sediments. The downcore variability of the phytane $/ n-\mathrm{C}_{18}$ ratio (Fig. 4 ) suggests that the extent of bioturbation, and perhaps seasonal water column anoxia, has fluctuated considerably during the last 200 years in Coburn Mountain Pond.

Pristane, another important isoprenoid hydrocarbon that is typically present in modern sediments, was absent from all of the sediment samples. Pristane has two principal sources. In young sediments, its presence reflects the digestive tract preprocessing of chlorophyll $a$ by planktonic herbivores such as calanoid copepods (Blumer et al., 1963). It is also produced from the phytol sidechain of chlorophyll $a$ during later diagenesis. Erosion of sedimentary rocks in the watershed is a potential source of the diagenetic pristane in the sediments of some lakes (e.g., Giger et al., 1980. The absence of pristane in the sediments of Coburn Pond indicates that the food chain of this tarn does not produce this hydrocarbon and that the surrounding rocks have not contributed ancient hydrocarbons to the sediments.

\subsection{Compositions of long-chain acid and alcohol fractions}

The molecular compositions of the $n$-alkanoic acids and $n$-alkanol fractions contrast to 


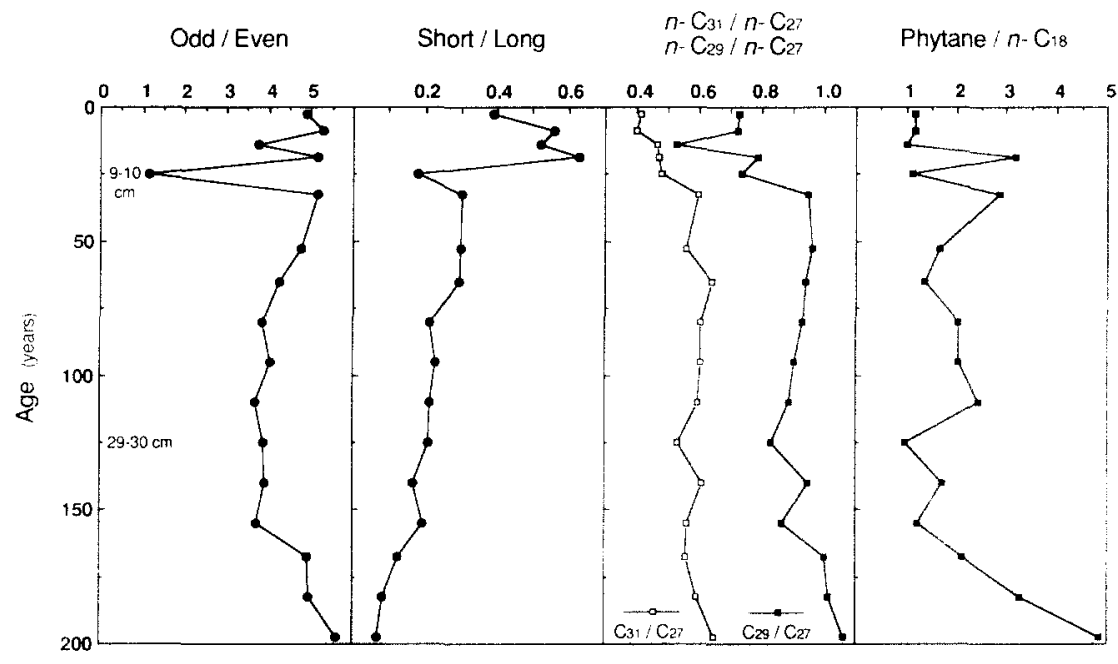

Fig. 4. Ratios of selected saturated hydrocarbon components extracted from sediment core sections from Coburn Pond. Odd/even ratios of $n$-alkanes calculated over the range of $C_{15}$ to $C_{30}$. Short/long $n$-alkane ratios are the concentrations of $\mathrm{C}_{15}+\mathrm{C}_{17}+\mathrm{C}_{19}$ divided by those of $\mathrm{C}_{27}+\mathrm{C}_{29}+\mathrm{C}_{31}$ and indicate aquatic/terrigenous sources. $n-\mathrm{C}_{31} / n-\mathrm{C}_{27}$ ratios characterize herbaceous/arboreal long-chain alkane sources. Phytane $/ n-\mathrm{C}_{18}$ ratios characterize methanogen/algal sources. Approximate years of deposition are given as determined by ${ }^{210} \mathrm{~Pb}$ and ${ }^{137} \mathrm{Cs}$ radiodating by Norton et al. (1981).

those of the $n$-alkanes in being quite variable with depth in the tarn sediment. The ratios of even-carbon-numbered to odd-carbon-numbered $n$-acids and $n$-alkanols are typically high in fresh biological material (e.g., Cranwell, 1982). Even-carbon-numbered components dominate the distributions of $n$-acids and $n$-alkanols in these sediments (Fig. 2). The major $n$-alkanol in nearly all of the seventeen core sections is $n-\mathrm{C}_{22}$, an alcohol which has been attributed to land-plant (Cranwell, 1982) or possibly microbial origin (Cranwell, 1981). Important contributions of land-plant $n$-alkanoic acids are shown by the large proportions of $\mathrm{C}_{24}, \mathrm{C}_{26}$ and $\mathrm{C}_{28}$ components (Rieley et al., 1991 ), although the ubiquitous $n-C_{16}$ acid is one of the major components in all core sections.

Diagenetic reworking of these lipid components typically diminishes the strong even-carbon-number preference of biological lipids as original components are replaced by microbial components. The even/odd ratios of both $n$ alkanoic acids and $n$-alkanols fluctuate widely between values of 1 and 8 independently of depth in the sediments of Coburn Pond (Fig. 5 ). The two ratios have an antithetical pattern, which may indicate microbial resynthesis of $n$ alkanoic acids at the expense of the $n$-alkanols. The short/long ratios of these two fractions also are variable (Fig. 5). Short-chain acids are commonly degraded preferentially by microbes during early diagenesis (e.g., Matsuda, 1978; Cranwell, 1984; Kawamura and Ishiwatari, 1984; Meyers et al., 1984b), and a similar selective degradation has been observed for $n$ alkanols (Robinson et al., 1984). Changes in the relative proportions of the lipids produced from algae, watershed flora and microbes can add to modifying the short/long ratios. For example, microbial synthesis of secondary fatty acids from primary organic matter creates shorter-chain components which may elevate short/long $n$-acid ratios (e.g., Kawamura et al., 1987).

We modified the OEP calculation of Scalan and Smith (1970) to produce even/odd predominance (EOP) values for the distributions of $n$-alkanols and $n$-alkanoic acids (Fig. 3 ). The EOP patterns differ significantly from the OEP 


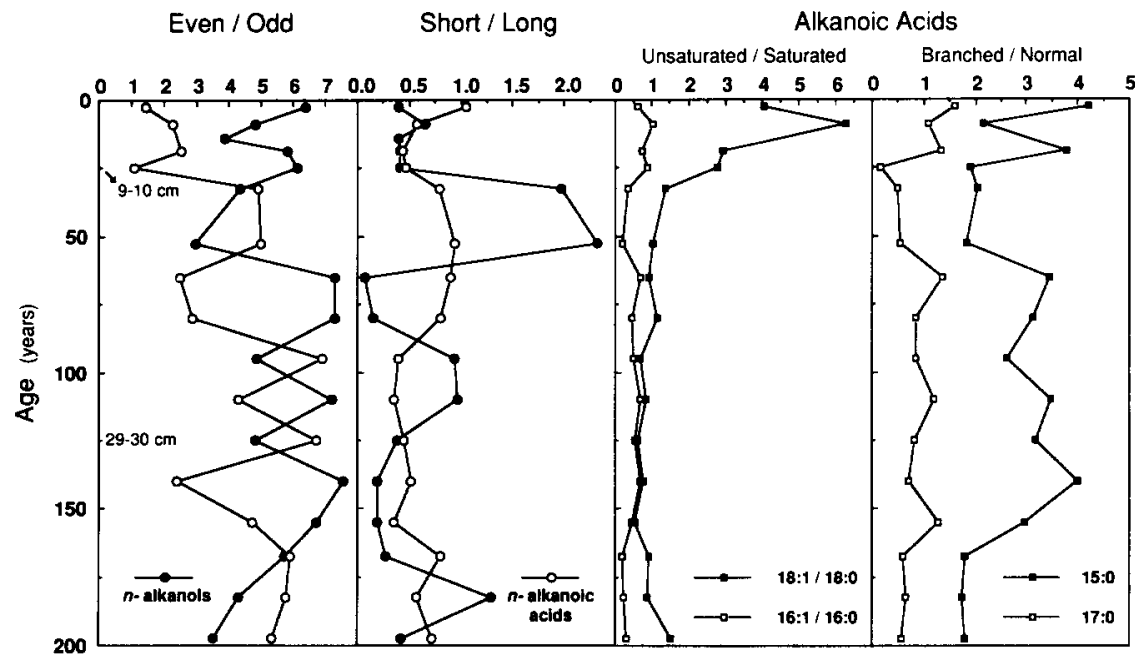

Fig. 5. Ratios of selected components of extractable fatty acids and $n$-alkanols. Even/odd ratios are determined from $\mathrm{C}_{14}$ to $C_{31}$. Short/long ratios are calculated from the concentrations of $C_{14}+C_{16}+C_{18}$ divided by those of $C_{24}+C_{26}+C_{28}$ and approximate aquatic/terrigenous sources. Unsaturated/saturated fatty acid components are represented by $\mathrm{C}_{18: 1} / \mathrm{C}_{18: 0}$ (cis-9-octadecenoic acid/octadecanoic acid) and by $\mathrm{C}_{16: 1} / \mathrm{C}_{16: 0}$ (cis-9-hexadecenoic acid/hexadecanoic acid). The ratios of (iso+anteiso) $-\mathrm{C}_{15: 0} / n-\mathrm{C}_{15: 0}$ and iso $-\mathrm{C}_{17: 0} / n-\mathrm{C}_{17: 0}$ characterizes the proportion of microbial fatty acids. Approximate sediment ages are given as determined by ${ }^{210} \mathrm{~Pb}$ and ${ }^{137} \mathrm{Cs}$ radiodating by Norton et al. (1981).

patterns, in which the chain-length preferences of the original source hydrocarbons were relatively well preserved. Neither the algal (short chain) nor the land-plant (long chain) components in the $n$-alkanol and $n$-alkanoic acid distributions are as well preserved as those in the $n$-alkane distributions. Instead, substitution of secondary components appears, most noticeably around $\mathrm{C}_{22}$ and $\mathrm{C}_{23}$ in the $n$-alkanol distributions and at $C_{16}$ in the $n$-alkanoic acid distributions. These contributions presumably derive from microbial activity in the sediments, an important element of early diagenesis.

The variability exhibited by the various ratios of $n$-alkanoic acid and $n$-alkanol components suggests that the amount of early diagenetic alteration of these geolipid fractions has fluctuated through time. Substantial amounts of preprocessing of organic matter and some of its lipid components can occur during sinking within lake waters and before incorporation into the lake bottom (e.g., Meyers et al., 1980b, 1984b; Robinson et al., 1984; Kawamura et al., 1987; Goossens et al., 1989; Meyers and Ea- die, 1993). The 3.5-m maximum depth of this tarn, however, allows only a brief sinking time, suggesting that most of the early diagenesis happens in the bottom sediments. Unsaturated acids are especially susceptible to early diagenetic degradation in lake sediments (e.g., Matsuda and Koyama, 1977a; Meyers et al., $1980 \mathrm{a})$. The ratio of $\mathrm{cis}-9$-octadecanoic acid to $n$-octadecanoic acid is 4-6 in the upper sections of Coburn Pond sediments (Fig. 5), which is relatively high and indicates good preservation of the unsaturated acids prior to sedimentation. This ratio drops to between 1 and 3 in deeper sediments. In contrast, the ratio of $c i s$-9-hexadecanoic acid to $n$-hexadecanoic acid remains between 0.2 and 1 throughout the core. Evidently, most of the limited destruction of unsaturated fatty acids occurs in the upper part of the sediments, and a significant proportion of the unsaturated acids survives in the deeper sediments of this tarn. Such preservation of unsaturated acids is atypical of most lake sediments, but it is consistent with the generally high degree of organic matter preservation indicated by the elevated concen- 


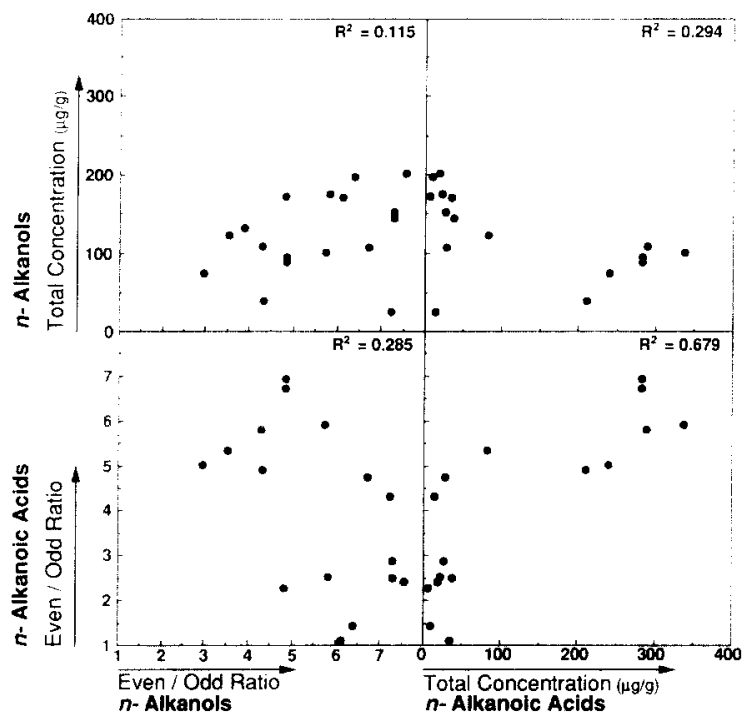

Fig. 6. Comparisons of even/odd ratios and total concentrations of $n$-alkanoic acids and $n$-alkanols extracted from sediments of Coburn Mountain Pond. Correlation coefficients of the acids indicate a fairly strong relationship between low even/odd ratios and low total concentrations for $n$-acids, but a weak relationship for $n$-alkanols. Neither even/odd ratios nor concentrations of $n$-alkanoic acids and $n$-alkanols correlate in this sediment core.

trations of organic carbon throughout this sediment core (Fig. 1).

Contributions of microbial alkanoic acids typically contain a large proportion of iso and anteiso branched components (Leo and Parker, 1966; Cooper and Blumer, 1968; Cranwell, 1973b, 1974; Johns et al., 1977; Goossens et al., 1986). The ratio of the sum of iso- and anteiso- $\mathrm{C}_{15}$ acids to $n-\mathrm{C}_{15}$ varies irregularly between 2 and 4 with depth (Fig. 5). The irregular pattern is mimicked by the ratio of iso- $\mathrm{C}_{17}$ to $n-\mathrm{C}_{17}$ (Fig. 5 ). The microbial fatty acids are relatively large components of the total fatty acid contents of the sediments, often exceeding their straight-chain analogs. The downcore patterns of the branched/normal ratios indicate that microbial activity has been an important and variable agent in modifying the organic matter in these tarn sediments.

The relatively constant concentrations of to- tal organic carbon in the pre-1950 and post1950 portions of this core (Fig. 1) imply that contributions of organic matter were more or less constant in these two intervals. Absolute concentrations of lipid fractions can therefore be used to assess the extent of microbial reprocessing of these organic matter components. The concentrations of $n$-alkanoic acids and of $n$-alkanols vary with depth (Fig. 1), as do the $n$-alkanoic acid and $n$-alkanol even/odd ratios (Fig. 5). Comparison of the $n$-alkanoic acid even/odd ratios relative to the total concentrations of these lipids reveals that both covary and that both are low in the same samples (Fig. 6 ). Similarly, the patterns of the $n$-alkanol concentrations (Fig. 1) and even/odd ratios (Fig. 5) fluctuate together with depth. Their correlation (Fig. 6) is poor, however, probably because of the dominance of the $\mathrm{C}_{22} n$-alkanol in most distributions. This component possibly originates from microbial activity in the bottom sediments of this tarn (Cranwell, 1981 ), and its dominance enhances the even/ odd ratios of this lipid fraction.

The fatty acid and fatty alcohol fractions share some impacts of early diagenesis, but they also have distinctive responses. Comparison of the total concentrations of the $n$-alkanoic acids and of the $n$-alkanols shows that the acid concentrations vary widely, regardless of sediment depth, whereas the alkanol concentrations are less variable (Figs. 1 and 6). As observed in Fig. 5, the even/odd ratios of the acids and alkanols seem to vary inversely in this sediment core. Statistical comparison of these ratios shows this observation to be true, although not strongly developed (Fig. 6). At those sediment depths where $n$-alkanoic acid concentrations are high, their even/odd ratios are also high, suggesting limited microbial destruction of these lipids. In most of the samples having high $n$-alkanol even/odd ratios, the $n$-alkanoic acid even/odd ratios are low. $\mathrm{Mi}$ crobial activity evidently depresses the $n$-acid ratio but can elevate the $n$-alkanol ratio, presumably by production of the $n-\mathrm{C}_{22}$ alcohol. 


\section{Summary and conclusions}

The changes in organic matter composition in the sediment core from Coburn Mountain Pond indicate that the amount of diagenetic alteration have varied repeatedly over the 200 $\mathrm{yr}$ record of this core. Source changes have also evidently occurred but they have been relatively minor and have been largely confined to sediments deposited after ca. 1950. Organic matter $\mathrm{C} / \mathrm{N}$ ratios, organic carbon $\delta^{13} \mathrm{C}$-values and $n$-alkane compositions reflect generally uniform organic matter sources within the periods separated by this time. The amount of diagenetic alteration of fatty acids and fatty alcohols, however, has been highly variable and has not been related to sediment depth or to a specific time.

Microbial alteration of organic matter, a major element in early diagenesis, typically produces a number of progressive changes in the fatty acid and fatty alcohol contents of sediments. The absence of progressive diminishments in the amounts and characteristics of both alkanoic acids and alkanols indicates that the rate of microbial utilization of these easily metabolizable lipid classes has varied at different times in the 200-yr record of the sediment core. The observed changes in the sediments of this isolated tarn include:

(1) Increased aquatic productivity is recorded by lower $\mathrm{C} / \mathrm{N}$ ratios, larger proportions of the $n-\mathrm{C}_{17}$ alkane and a higher organic carbon accumulation rate in sediments deposited since ca. 1950. A shift to more negative $\delta^{13} \mathrm{C}$ values in post-1950 organic matter appears to result from lake acidification.

(2) Absolute concentrations of $n$-alkanoic acids and of $n$-alkanols vary erratically with depth. Because total organic carbon varies narrowly between $21 \%$ and $25 \%$ in this core, the lipid concentrations relative to total organic matter are variable, rather than changing progressively with depth.

(3) Even/odd ratios of the alkanoic acid and alkanol fractions vary randomly with sedi- ment depth. Progressive decreases in the original even-carbon predominance in the straightchain components would be expected if de novo microbial synthesis of these lipids had proceeded progressively with time.

(4) Progressive modification of the proportions of short-chain $\left(\mathrm{C}_{14}\right.$ to $\left.\mathrm{C}_{18}\right) n$-alkanoic acids and $n$-alkanols from the originally sedimented lipid compositions is absent. Two microbial processes affect these short-chain components in opposite ways - their preferential destruction during early diagenesis and their de novo microbial production. The short/long ratios are variable with depth, indicating that both destruction and resynthesis have been variable over time.

(5) Production of branched-chain bacterial lipid components has occurred. The sediments of Coburn Pond contain relatively high proportions of branched fatty acids, indicating that microbial activity has been extensive, albeit not at a steady rate.

The extent of early diagenetic alteration of the relatively reactive alkanoic acids and alkanols is clearly variable with sediment depth. This variability can have many origins, but the strength and duration of thermal stratification of this tarn is likely to be the principal cause. This, in turn, is an expression of local weather - winds and seasonal temperatures - which impacts a shallow lake more than it would a deep lake. The small volume of Coburn Mountain Pond (maximum depth $3.5 \mathrm{~m}$ ) makes it very sensitive to variations in wind-driven mixing. Larger water bodies would absorb similar perturbations in mixing and consequently not exhibit the diagenetic variability evident in this tarn.

The variable diagenesis evident in the organic constituents of these lake sediments is likely to have occurred in other shallow lakes, although lower sedimentation rates or more extensive sediment mixing might mask its effects. Like the organic matter, inorganic species would have also been affected by the variations in post-depositional conditions. 


\section{Acknowledgments}

We thank S.A. Norton for the sediment samples from Coburn Pond and R.A. Hites for providing laboratory extraction facilities while P.A.M. was a guest investigator at Indiana University in 1980 . L. Walter kindly allowed us use of the Coulometrics ${ }^{\circledR}$ Carbon Analyzer. P.A. Cranwell and an anonymous reviewer provided many helpful and thought-provoking comments which improved this paper. The assistance of Sonja Pettingill in doing the fatty acid analyses is deeply appreciated. Acknowledgment is made to the Donors of the Petroleum Research Fund, administered by the American Chemical Society, for partial support of this study.

\section{References}

Benner, R., Fogel, M.L., Sprague, E.K. and Hodson, R.E., 1987. Depletion of ${ }^{13} \mathrm{C}$ in lignin and its implications for stable carbon isotope studies. Nature (London), 329: 708-710.

Blumer, M., Mullin, M.M. and Thomas, D.S., 1963. Pristane in zooplankton. Science, 140: 974.

Blumer, M., Guillard, R.R.L. and Chase, T., 1971. Hydrocarbons of marine phytoplankton. Mar. Biol., 8 : 183-189.

Cooper, W.J. and Blumer, M., 1968. Linear, iso, and anteiso acids in Recent sediments of the North Atlantic. Deep-Sea Res., 15: 535-540.

Cranwell, P.A., 1973a. Chain-length distribution of $n$-alkanes from lake sediments in relation to post-glacial environmental change. Freshwater Biol., 3: 259-265.

Cranwell, P.A., 1973b. Branched-chain and cyclopropanoid acids in a Recent sediment. Chem. Geol., 11:307313.

Cranwell, P.A., 1974. Monocarboxylic acids in lake sediments: Indicators derived from terrestrial and aquatic biota of paleoenvironmental trophic levels. Chem. Geol., 14: 1-14.

Cranwell, P.A., 1977. Organic geochemistry of Cam Loch (Sutherland) sediments. Chem. Geol., 20: 205-221.

Cranwell, P.A., 1978. Extractable and bound lipid components in a freshwater sediment. Geochim. Cosmochim. Acta, 42: 1523-1532.

Cranwell, P.A., 1981. Diagenesis of free and bound lipids in terrestrial detritus deposited in a lacustrine sediment. Org. Geochem., 3: 79-89.

Cranwell, P.A., 1982. Lipids of aquatic sediments and sedimenting particulates. Prog. Lipid Res., 21: 271 308.

Cranwell, P.A., 1984. Lipid geochemistry of sediments from Upton Broad, a small productive lake. Org. Geochem., 7: 25-37.

Cranwell, P.A. and Volkman, J.K., 1981. Alkyl and steryl esters in a recent lacustrine sediment. Chem. Geol., 32: 29-43.

Cranwell, P.A., Eglinton, G. and Robinson, N., 1987. Lipids of aquatic organisms as potential contributors to lacustrine sediments, II. Org. Geochem., 11: 513-527.

Eglinton, G. and Hamilton, R.J., 1963. The distribution of alkanes. In: T. Swaine (Editor), Chemical Plant Taxonomy. Academic Press, London, pp. 187-217.

Eglinton, G. and Hamilton, R.J., 1967. Leaf epicuticular waxes. Science, 156: 1322-1335.

Engleman, E.E., Jackson, L.L. and Norton, D.R., 1985. Determination of carbonate carbon in geological materials by the coulometric titration. Chem. Geol., 53: 125-128.

Giger, W., Schaffner, C. and Wakeham, S.C., 1980. Aliphatic and olefinic hydrocarbons in recent sediments of Greifensee, Switzerland. Geochim. Cosmochim. Acta, 44: 119-129.

Goossens, H., Rijpstra, I.C., Düren, R.R., de Leeuw, J.W. and Schenck, P.A., 1986. Bacterial contribution to sedimentary organic matter; a comparative study of lipid moieties in bacteria and Recent sediments. Org. Geochem., 10: 683-696.

Goossens, H., Düren, R.R., de Leeuw, J.W. and Schenck, P.A., 1989. Lipids and their mode of occurrence in bacteria and sediments, II. Lipids in the sediment of a stratified, freshwater lake. Org. Geochem., 14: 27-41.

Gschwend, P.M. and Hites, R.A., 1981. Fluxes of polycyclic aromatic hydrocarbons to marine and lacustrine sediments in the northeastern United States. Geochim. Cosmochim. Acta, 45: 2359-2367.

Gschwend, P.M., Chen, P.H. and Hites, R.A., 1983. On the formation of perylene in recent sediments: Kinetic models. Geochim. Cosmochim. Acta, 47: 2115-2119.

Hatcher, P.G., Simoneit, B.R.T., Mackenzie, F.T., Neumann, A.C., Thorstenson, D.C. and Gerchakov, S.M., 1982. Organic geochemistry and pore water chemistry of sediments from Mangrove Lake, Bermuda. Org. Geochem., 4: 93-112.

Hatcher, P.G., Spiker, E.C., Szeverenyi, N.M. and Maciel, G.E., 1983. Selective preservation and origin of petroleum-forming aquatic kerogen. Nature (London ), 305: 498-501.

Ho, E.S., Meyers, P.A. and Pettingill, S., 1991. Geolipid content of sediments from an isolated lake: Evidence of diagenetic alteration of source indicators. In: J. Berthelin (Editor), Proceedings 8th International Meeting on Environmental Biogeochemistry. Elsevier, Amsterdam, pp. 67-75.

Hollander, D.J. and McKenzie, J.A., 1991. $\mathrm{CO}_{2}$ control 
on carbon-isotope fractionation during aqueous photosynthesis: A paleo- $p_{\mathrm{CO} 2}$ barometer. Geol., 19: $929-$ 932.

Jasper, J.P. and Gagosian, R.B., 1989. Glacial-interglacial climatically forced $\delta^{13} \mathrm{C}$ variations in sedimentary organic matter. Nature (London), 342: 60-62.

Johns, R.B., Perry, G.J. and Jackson, K.S., 1977. Contributions of bacterial lipids to recent marine sediments. Estuarine Coast. Mar. Sci., 5: 521-529.

Kawamura, K. and Ishiwatari, R., 1984. Fatty acid geochemistry of a $200 \mathrm{~m}$ sediment core from Lake Biwa, Japan - Early diagenesis and paleoenvironmental information. Geochim. Cosmochim. Acta, 48: 251-266.

Kawamura, K. and Ishiwatari, R., 1985. Distribution of lipid-class compounds in bottom sediments of freshwater lakes with different trophic status, in Japan. Chem. Geol., 51: 123-133.

Kawamura, K., Ishiwatari, R. and Yamazaki, M., 1980. Identification of polyunsaturated fatty acids in surface lacustrine sediments. Chem. Geol., 28: 31-39.

Kawamura, K., Ishiwatari, R. and Ogura, K., 1987. Early diagenesis of organic matter in the water column and sediments: Microbial degradation and resynthesis of lipids in Lake Haruna. Org. Geochem., 11: 251-264.

Leenheer, M.J., Flessland, K.D. and Meyers, P.A., 1984. Comparison of lipid character of sediments from the Great Lakes and the Northwestern Atlantic. Org. Geochem., 7: 141-150.

Leo, R.E. and Parker, P.L., 1966. Branched-chain fatty acids in sediments. Science, 152: 649-650.

Matsuda, H., 1978. Early diagenesis of fatty acids in lacustrine sediments, III. Changes in fatty acid composition in the sediments from a brackish lake. Geochim. Cosmochim. Acta, 42: 1027-1034.

Matsuda, H. and Koyama, T., 1977a. Early diagenesis of fatty acids in lacustrine sediments, I. Identification and distribution of fatty acids in recent sediment from a freshwater lake. Geochim. Cosmochim. Acta, 41: 777 783.

Matsuda, H. and Koyama, T., 1977b. Early diagenesis of fatty acids in lacustrine sediments, II. A statistical approach to changes in fatty acid composition in recent sediments and source materials. Geochim. Cosmochim. Acta, 41: 1825-1834.

Mendoza, Y.A., Gülaçar, F.O., Hu, Z.-L. and Buchs, A., 1987. Unsubstituted and hydroxy substituted fatty acids in a recent lacustrine sediment. Int. J. Environ. Anal. Chem., 31: 107-127.

Meyers, P.A., 1990. Impacts of late Quaternary fluctuations in water level on the accumulation of sedimentary organic matter in Walker Lake, Nevada. Palaeogeogr., Palaeoclimatol., Palaeoecol., 78: 229-240.

Meyers, P.A. and Eadie, B.J., 1993. Sources, degradation, and recycling of organic matter associated with sinking particles in Lake Michigan. Org. Geochem., 20: 47 56.
Meyers, P.A. and Takeuchi, N., 1979. Fatty acids and hydrocarbons in surficial sediments of Lake Huron. Org. Geochem., 1: 127-138.

Meyers, P.A., Bourbonniere, R.A. and Takeuchi, N., 1980a. Hydrocarbons and fatty acids in two cores of Lake Huron sediments. Geochim. Cosmochim. Acta, 44: $1215-1221$.

Meyers, P.A., Edwards, S.J. and Eadie, B.J., 1980b. Fatty acid and hydrocarbon content of settling sediments in Lake Michigan. J. Great Lakes Res., 6: 331-337.

Meyers, P.A., Maring, H.B. and Bourbonniere, R.A., 1980c. Alkane and alkanoic acid variations with depth in modern sediments of Pyramid Lake. In: A.G. Douglas and J.R. Maxwell (Editors), Advances in Organic Geochemistry 1979. Pergamon, Oxford, pp. 365-374.

Meyers, P.A., Kawka, O.E. and Whitehead, D.R., 1984a. Geolipid, pollen and diatom stratigraphy in postglacial lacustrine sediments. Org. Geochem., 6: 727-732.

Meyers, P.A., Leenheer, M.J., Eadie, B.J. and Maule, S.J., 1984b. Organic geochemistry of suspended and settling particulate matter in Lake Michigan. Geochim. Cosmochim. Acta, 48: 443-452.

Murphy, M.T.J., 1969. Analytical Methods. In: G. Eglinton and M.T.J. Murphy (Editors), Organic Geochemistry - Methods and Results. Springer, New York, N.Y., pp. 74-88.

Norton, S.A., Hess, C.T. and Davis, R.B., 1981. Rates of accumulation of heavy metals in pre- and post-European sediments in New England lakes. In: S.J. Eisenrich (Editor), Atmospheric Pollutants in Natural Waters. Ann Arbor Science, Ann Arbor, Mich., pp. 409-421.

Prahl, F.G. and Carpenter, R., 1984. Hydrocarbons in Washington coastal sediments. Estuarine Coast. Shelf Sci., 18: 703-720.

Reed, W.E., 1977. Biogeochemistry of Mono Lake, California. Geochim. Cosmochim. Acta, 41: 1231-1245.

Rieley, G., Collier, R.J., Jones, D.M. and Eglinton, G., 1991. The biogeochemistry of Ellesmere Lake, U.K., I. Source correlation of leaf wax inputs to the sedimentary lipid record. Org. Geochem., 17: 901-912.

Risatti, J.B., Rowland, S.J., Yon, D. and Maxwell, J.R., 1984. Stereochemical studies of acyclic isoprenoids, XII. Lipids of methanogenic bacteria and possible contributions to sediments. In: P.A. Schenck and J.W. de Leeuw (Editors), Advances in Organic Geochemistry 1983. Pergamon, Oxford, pp. 93-103.

Robinson, N., Cranwell, P.A., Finlay, B.J. and Eglinton, G., 1984. Lipids of aquatic organisms as potential contributors to lacustrine sediments. Org. Geochem., 6: 143-152.

Sackett, W.M., Eadie, B.J. and Meyers, P.A., 1986. Stable carbon isotope studies of organic matter in Great Lakes sediments. Eos (Trans. Am. Geophys. Union), 76: 1058 (abstract).

Scalan, R.S. and Smith, J.E., 1970. An improved measure 
of the odd-even predominance in the normal alkanes of sediment extracts and petroleum. Geochim. Cosmochim. Acta, 34: 611-620.

Schelske, C.L. and Hodell, D.A., 1991. Recent changes in productivity and climate of Lake Ontario detected by isotopic analysis of sediments. Limnol. Oceanogr., 36: 961-975.

Sollins, P., Spycher, G. and Glassman, C.A., 1984. Net nitrogen mineralization from light-fraction and heavy fraction forest soil organic matter. Soil Biol. Biochem., 16: $31-37$. ten Haven, H.L., de Leeuw, J.W., Rullkötter, J. and Sinninghe Damsté, J.S., 1987. Restricted utility of the pristane/phytane ratio as a paleoenvironmental indicator. Nature (London), 330: 641-643.

Verardo, D.J., Froelich, P.N. and McIntyre, A., 1990. Determination of organic carbon and nitrogen in marine sediments using the Carlo Erba NA-1500 analyzer. Deep-Sea Res., 37: 157-165.

Wünsche, L., Mendoza, Y.A. and Gülaçar, F.O., 1988. Lipid geochemistry of a post-glacial lacustrine sediment. Org. Geochem., 13:1131-1143. 